\title{
A DIFFERENCE ANALYSIS OF PERFORMANCE SHARES BEFORE AND AFTER BUYBACK ANNOUNCEMENT: A CASE STUDY AT PT RAMAYANA LESTARI SENTOSA TBK AND PT ACE HARDWARER INDONESIA TBK OVER A PERIOD OF 2015
}

\author{
Husaini Achmad, Supriono, Natania Chaela* \\ Faculty of Administrative Science, University of Brawijaya, Malang, Indonesia \\ *E-mail: chaela.natania@gmail.com
}

\begin{abstract}
Stock buyback is a share repurchase by the company (issuer) which is one of the ways the company does to generate profits for shareholders. Stock buyback is part of investment strategy in order to increase company value. This study tries to observe the information content of the buyback policy that uses a variable of Return (R), Abnormal Return (AR), and Cumulative Abnormal Return (CAR). This was a descriptive research with a quantitative approach. The form of this research was an event study. The research result reveals that there is a significant difference in return before and after the stock buyback. The Abnormal Return shows that there is no significant difference in Abnormal Return before and after the stock buyback. The Cumulative Abnormal Return shows that there is a significant difference of Cumulative Abnormal Return before and after the stock buyback.
\end{abstract}

\section{KEY WORDS}

Stock buyback, return, abnormal return, cumulative abnormal return.

A company has been listed on the capital market has information consequence of the involved company which will spread largely to the investor in the capital market. One of the information related to the company policy is information about the corporate action, which is issuer activity that impacts on the total issued stock or the stock price at the market, which one of its forms is the stock buyback. Stock buyback is share repurchase by a company which is one of the company's methods to generate benefits for the shareholder. Stock buyback is part of investment strategy in order to increase company value.

Several purposes of buyback, among others, are to give signal to the market that the stock price is undervalued, to change capital structural, and to decrease free cash flow which can be misused by management. A motive frequently proposed by the management when conducting buyback is to increase Earnings per Share (EPS) which is a number that shows the company's net profit received every stock. Stock buyback influences EPS value, both through net profit and total issued stock. The impact of buyback on the total issued stock depends on buyback's timing. Stock buyback action reducing total issued stock does not automatically decrease EPS because buyback also influences net profit. Stock buyback action needs cash derives from the internal company or new debt. Net profit will be reduced by the return that actually is generated by the cash used for the stock buyback or will be decreased by the debt interest.

Stock buyback policy conducted by a company in Indonesia actually aims to increase the company's Earning Per Share (EPS) value finally expected will decrease stock price and Return for the investor. As long as the stock buyback does not bring a conflict of interest among the shareholder, all activities of stock buyback will be agreed by the shareholder.

For an investor, stock buyback policy has profits potential in the future, among other things, buyback policy is frequently considered positive for an investor because generally buyback is conducted when a company feels that the stock price is undervalued. Stock buyback policy will decrease total issued stock in the market so that the possibility is the stock price will rise after stock buyback happens so that the investor has an option to either sell the stock or not.

This study aims to test the information content from the impact of stock buyback policy announcement that uses Return, Abnormal Return, and Cumulative Abnormal Return 
variable. The reason to choose that kind of variable is that stock buyback is one of the corporate actions conducted to increase company value. EPS increase impacts on the price increase of company's stock that reflect company value so that the increase of price stock can increase the company value. Based on the phenomenon that has been described so it consideres important to carry out an event study about "A Difference Analysis of Performance Shares Before and After Buyback Announcement. (A Case Study at PT Ramayana Lestari Sentosa Tbk and PT Ace Hardware Indonesia Tbk Over the Period 2015)".

\section{LITERATURE REVIEW}

According to Hartono (2014), capital market is a company's facility to improve longterm funding needs by selling stock or issuing obligation. Husnan (205) explains that capital market can be formally defined as a market for various long-term financial instruments (security) which is sold and bought, either in the form of debt or self-funded, issued by the government, public authorities or private company.

Stock is a security issued by a Public limited company or commonly known as issuer (Sunariyah, 2006). Stock is an ownership proof of part of a company.

Capital Market Efficiency. The first time Fama said about efficient market hypothesis was in his writing in 1965. Efficient market is a condition where security price fully reflects the existing information (Fama, 1970). A market is said efficient if the reaction of the market towards new information is very quick and not bias.

Corporate Action. Corporate Action is an issuer's corporate action that has an influence on the total issued stock or stock price at the market. Corporation action is information that generally attracts involved parties' attention at the capital market, especially the shareholder (Darmadji and Fakhruddin, 2001).

Stock Buyback. Stock buyback is a share repurchase by the company which issues in an open market or through repurchase offers (Horne and Wachowicz, 2007). Stock buyback is another form conducted by a company to distribute cash flow owned by a company to the shareholder except in the forms of a dividend.

Return. Stock return is the result obtained from share investment conducted over the observation period (Hartono, 2014). Stock return calculation uses the following formulation:

$$
R_{i, t}=\frac{P_{i,}-P_{i, t-1}}{P_{i,-1}}
$$

Where: $R i,=$ Stock return $\mathrm{i}$ on day $\mathrm{t} ; P i, t=$ Stock price $\mathrm{i}$ on day $\mathrm{t} ; P i, t-1=$ Stock price $\mathrm{i}$ before day t.

Abnormal return is the benefits of the return that actually happens on the normal return (Hartono, 2014). Calculation abnormal return uses this following formula:

$$
A R_{i,}=R_{i, t}-\mathrm{E}\left(R_{i, t}\right)
$$

Where: $A R i,=$ Abnormal return security $\mathrm{i}$ on period $\mathrm{t} ; R i, t=$ Actual return security $\mathrm{i}$ on period $\mathrm{t} ; \mathrm{E}(R i, t)=$ Expected return security $\mathrm{i}$ on period $\mathrm{t}$.

Cumulative Abnormal Return is the calculation of abnormal return of the previous day in the circumstance period for each security (Hartono, 2014). CAR is calculated by using this following formula:

$$
C A R_{i, t}=\sum A R_{i, t}
$$

Where: $C A R i,=$ Cumulative abnormal return security $\mathrm{i}$ on period $\mathrm{t} ; A R i, t=$ Abnormal return security $i$ on period $t$. 
The Relationship of Return, Abnormal Return, and Cumulative Abnormal Return with Buyback Stock. A study about the influence of an event on the stock price or share return is conducted through an event study, which is an empirical study carried out to observe stock price movements in the capital market when something happens and to determine whether or not there is an unusual investment return received by an investor as a result of that circumstance. Information content assessment aims to see the reaction of an announcement if the announcement contains information so a market will react at the time that announcements receive by the market. Market reaction is shown by the existence of price changes from the involved security. The reaction is measured by using return as a value of price changes or by using abnormal return.

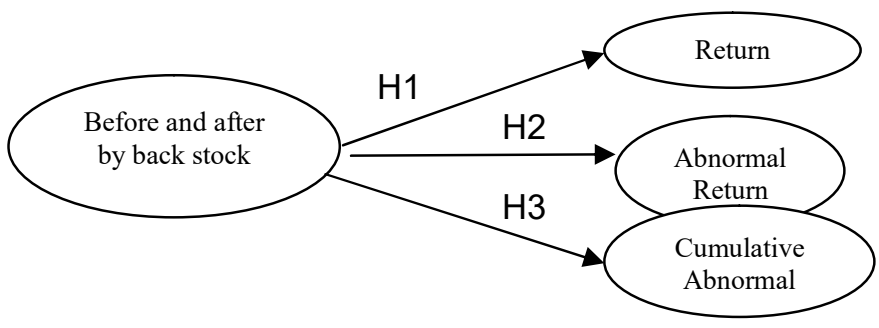

Figure 1 - Hypothesis Model

$\mathrm{H}_{1}=$ There is a significant difference on the Return between PT Ramayana Lestari Sentosa Tbk and PT Ace Hardware Indonesia Tbk before and after stock buyback.

$\mathrm{H}_{2}=$ There is a significant difference on the Abnormal Return between PT Ramayana Lestari Sentosa Tbk and PT Ace Hardware Indonesia Tbk before and after stock buyback.

$\mathrm{H}_{3}=$ There is a significant difference on Cumulative Abnormal Return of PT Ramayana Lestari Sentosa and PT Ace Hardware Indonesia Tbk before and after stock buyback.

\section{METHODS OF RESEARCH}

This was a descriptive research with a quantitative approach. The form of this research was an event study. An event study is a study to learn about the market reaction or a circumstance whose information published in the form of an announcement (Hartono, 2014).

This research was carried out for 20 days, which were 10 days before and 10 days after the date of the announcement. The reason to choose that kind of period is due to the consideration of Indonesia capital market condition categorized emerging capital market since is still influenced by politics, economics, and government regulation so that the information received by the investor is not as quick as of capital market in a developed country.

Source of data used was in the form of secondary data obtained from the data that has been published originating from PT ISE through the website www.idx.co.id and another publication containing information still relevant to this research. Http://www.idx.co.id/

The population of this research was stock price recapitulation data of PT Ramayana Lestari Sentosa Tbk and PT Ace Hardware Tbk in 2015. The sample collected by the writer was stock price recapitulation data of 10 days before and 10 days after the announcement of the stock buyback of PT Ramayana Lestari Sentosa and PT Ace Hardware Tbk.

Descriptive statistics of this research aims to illustrate the average of the return, abnormal return, and cumulative abnormal return before and after stock buyback announcement.

Data normality test is conducted to know whether a data is normally distributed or not so that can be determined the test tool for hypothesis testing. Data normality test uses Kolmogorov-Smirnov Test with the base of decision making (Santoso, 2014) as follows:

- If the significance level $>0.05$ so that the data is normally distributed;

- If the significance level $<0.05$ so that the data is not normally distributed.

If the data is normally distributed so automatically applied parametrical statistic test of 
Paired Sample T-Test with the level of significance $(\alpha)=0.05$. The use of Paired Sample TTest to check a subject given two different treatments (Santoso, 2014). The criteria selected to make a decision is:

- If the significance value $(\alpha)>0.05$ so $\mathrm{H}_{0}$ is accepted and $\mathrm{H}_{1}$ is rejected;

- If significance value $(\alpha)<0.05$ so that $\mathrm{H}_{0}$ is rejected and $\mathrm{H}_{1}$ is accepted.

\section{RESULTS AND DISCUSSION}

Table 1 - Stock Return of PT Ramayana Lestari Tbk

\begin{tabular}{|c|c|c|c|}
\hline over the Period 2015 & Average & The highest & The lowest \\
\hline Before & -0.01298 & 0.01460 & -0.0625 \\
\hline After & 0.01373 & 0.13592 & -0.03306 \\
\hline
\end{tabular}

Source: Processed Data (2017).

Table 2 - The Stock Return of PT Ace Hardware Indonesia Tbk

\begin{tabular}{|c|c|c|c|}
\hline over the Period 2015 & Average & The highest & The lowest \\
\hline Before & -0.00561 & 0.10526 & -0.07937 \\
\hline After & -0.00676 & 0.01770 & -0.04202 \\
\hline
\end{tabular}

Source: Processed Data (2017).

Table 3 - The Abnormal Stock Return of PT Ramayana Lestari Sentosa Tbk

\begin{tabular}{|c|c|c|c|}
\hline over the Period 2015 & Average & The highest & The lowest \\
\hline Before & 0.04395 & 0.07155 & -0.0057 \\
\hline After & 0.07076 & 0.19303 & 0.02379 \\
\hline
\end{tabular}

Source: Processed Data (2017).

Table 4 - The Stock Abnormal Return of PT Ace Hardware Indonesia Tbk

\begin{tabular}{|c|c|c|c|}
\hline over the Period 2015 & Average & The highest & The lowest \\
\hline Before & 0.04509 & 0.15773 & -0.03033 \\
\hline After & 0.04307 & 0.06725 & 0.00932 \\
\hline
\end{tabular}

Source: Processed Data (2017).

Table 5 - The Cumulative Abnormal Return of the Stock of PT Ramayana Lestari Sentosa Tbk

\begin{tabular}{|c|c|c|c|}
\hline over the Period 2015 & Average & The highest & The lowest \\
\hline Before & 0.27881 & 0.4452 & 0.071546 \\
\hline After & 0.82114 & 1.062 .157 & 0.54762 \\
\hline
\end{tabular}

Source: Processed Data (2017).

Table 6 - The Cumulative Abnormal Return of The Stock of PT Ace Hardware Indonesia Tbk

\begin{tabular}{|c|c|c|c|}
\hline over the Period 2015 & Average & The highest & The lowest \\
\hline Before & 0.23225 & 0.481261 & 0.003263 \\
\hline After & 0.76752 & 0.965993 & 0.59079 \\
\hline
\end{tabular}

Source: Processed Data (2017).

Table 7 - Test Result of Data Normality of PT Ramayan Lestari Sentosa Tbk

\begin{tabular}{|c|c|c|c|}
\hline Variable & Periode & Kolmogorov Smirnov Z & Significance \\
\hline \multirow{2}{*}{ Return } & Before & 1,113 & 0,168 \\
\cline { 2 - 4 } & After & 0,945 & 0,334 \\
\hline \multirow{2}{*}{ Abnormal Return } & Before & 1,114 & 0,164 \\
\cline { 2 - 4 } & After & 0,945 & 0,333 \\
\hline \multirow{2}{*}{ Cumulative abnormal return } & Before & 0,407 & 0,996 \\
\cline { 2 - 4 } & After & 0,229 & 1,000 \\
\hline
\end{tabular}

Source: Processed Data (2017). 
Based on the result of data normality testing in table 7 above, the significance value of all variables is 0.05 which means all data are normally distributed. Hence, the data is analyzed using parametric statistic of paired sample t-test.

Table 8 - Data Normality Test Result of PT Ace Hardware Indonesia Tbk

\begin{tabular}{|c|c|c|c|}
\hline Variable & Periode & Kolmogorov Smirnov Z & Significance \\
\hline \multirow{2}{*}{ Return } & Before & 0,698 & 0,715 \\
\cline { 2 - 4 } & After & 0,784 & 0,571 \\
\hline \multirow{2}{*}{ Abnormal Return } & Before & 0,678 & 0,747 \\
\cline { 2 - 4 } & After & 0,761 & 0,609 \\
\hline \multirow{2}{*}{ Cumulative abnormal return } & Before & 0,365 & 0,999 \\
\cline { 2 - 4 } & After & 0,471 & 0,979 \\
\hline
\end{tabular}

Source: Processed Data (2017).

Based on the result of data normality testing in table 8 above, the significance value of all data is 0.05 which means all data are normally distributed. Hence, the analysis of data uses parametric statistic of paired sample t test.

Table 9 - Paired Sample-T Test of Stock Return of PT Ramayana Lestari Sentosa Tbk

\begin{tabular}{|c|c|c|}
\hline Variable & $\mathrm{T}$ & Significance \\
\hline Before - after return & $-2,025$ & 0,073 \\
\hline
\end{tabular}

Source: Processed Data (2017).

Table 9 above shows the result of discrimination test by using paired sample t-test which proves that the value of t-test reaches up to -2.025 and the significance value is 0.073 $>0.05$ so that decided to receive $\mathrm{H}_{0}$ and reject $\mathrm{H}_{1}$.

Table 10 - Paired Sample T-Test of The Stock Return of PT Ace Hardware Indonesia Tbk

\begin{tabular}{|c|c|c|}
\hline Variable & $\mathrm{T}$ & Significance \\
\hline Before - after return & 0,066 & 0,949 \\
\hline
\end{tabular}

Source: Processed Data (2017).

Table 10 above shows that the value of t-test is 0.066 and the significance value is $0.949>0.05$ so that the decision is to receive $\mathrm{H}_{0}$ and to reject $\mathrm{H}_{1}$. That matter concludes that the stock return of PT Ace Hardware Indonesia Tbk is not significantly different before and after the stock buyback.

Table 11 - Paired Sample T-Test of Abnormal Return of PT Ramayan Sentosa Tbk's Stock

\begin{tabular}{|c|c|c|}
\hline Variable & $T$ & Significance \\
\hline Before - after return & $-2,030$ & 0,073 \\
\hline
\end{tabular}

Source: Processed Data (2017).

Table 11 above shows that the discrimination test result by using paired sample t-test proves that the statement about the significant difference of abnormal return before and after the stock buyback cannot be accepted. That matter can be seen from the t-test value by 2.030 and significance value by $0.73>0.05$ which decides to accept $\mathrm{H}_{0}$ and reject $\mathrm{H}_{2}$.

Table 12 - Paired Sample T-Test of Abnormal Return of PT Ace Hardware Indonesia Tbk's Stock

\begin{tabular}{|c|c|c|}
\hline Variable & $\mathrm{T}$ & Significance \\
\hline Before - after return & 0,116 & 0,910 \\
\hline
\end{tabular}

Source: Processed Data (2017).

Based on table 12 above, the result of paired sample t-test of abnormal return of PT Ace Hardware Indonesia Tbk before and after the stock buyback including t-test value and 
significance value by $5 \%$ or $\alpha=0.05$ which means that the trust level reaches up to $95 \%$. Table 30 above indicates that the result of discrimination test by using paired sample t-test method can prove that there is no significant difference of abnormal return before and after the stock buyback of PT Ace Hardware Indonesia Tbk. It can be seen from the table showing that t-test value by 0.116 and significant at $0.910>0.05$ which decides to accept.

Table 13 - Paired Sample T-Test of Cumulative Abnormal Return of the Stock of PT Ramayana Lestari Sentosa Tbk

\begin{tabular}{|c|c|c|}
\hline $\begin{array}{l}\text { Variable } \\
\end{array}$ & $\mathrm{T}$ & Significance \\
\hline Before - after Cumulative abnormal return & $-43,730$ & 0,000 \\
\hline
\end{tabular}

Source: Processed Data (2017).

The result of discrimination test by using paired sample t-test method proves that there is a significant difference of cumulative abnormal return before and after stock buyback. Table 13 above shows that t-test by -43.730 with significance value by $0.000<0.05$ means to receive $\mathrm{H}_{3}$ and to reject $\mathrm{H}_{0}$.

Table 14 - Paired Sample t-Test of Cumulative Abnormal Return of PT Ace Hardware Indonesia Tbk's Stock

\begin{tabular}{|c|c|c|}
\hline Variable & $\mathrm{T}$ & Significance \\
\hline Before - after Cumulative abnormal return & $-39,802$ & 0,000 \\
\hline
\end{tabular}

Source: Processed Data (2017).

Table 14 above shows discrimination test result by using paired sample t-test method proving that there is a significant difference of cumulative abnormal return before and after the stock buyback of PT Ace Hardware Indonesia Tbk. Table 14 above indicates that t-test by -39.802 and significance value of $0.000<0.05$ will receive $\mathrm{H}_{3}$ and reject $\mathrm{H}_{0}$

\section{DISCUSSION OF RESULTS}

The Result of Hypothesis I. The result of the statistical test on hypothesis 1 shows that there is no return difference before and after the announcement of an ongoing stock buyback. The reason why there is no significant difference in return is that the observation period is too short, which is 20 days only. Although there is no return difference before and after the announcement of the ongoing stock buyback at PT Ramayana Lestari Sentosa Tbk and PT Ace Hardware Indonesia Tbk, at that observation period, there are several days that need positive return after the stock buyback. The stock price fluctuation does not mean that the investor reacts and responds that information and assesses that information has information content economically having an influence of company return.

This means an investor does not react to the information and it is stated to not have information content. It is due to the investor tends to wait and see the announcement of the stock buyback of PT Ramayana Lestari Sentosa Tbk and PT Ace Hardware Indonesia Tbk to assess whether or not the stock buyback has a quite large economical value on the return of company stock. A positive return signs the relevance to asymmetric information hypothesis explained by Stephans and Weisbach (1998) stating that the stock price increase is the result of information provided by a company at the time of the stock buyback announcement that the stock is undervalued.

The Result of Hypothesis II. The result of the statistical test to Hypothesis II generates that there is no difference in the abnormal return of PT Ramayana Lestari Sentosa Tbk and PT Ace Hardware Indonesia Tbk before and after the stock buyback announcement. This means the information received by capital market actor is not different, so that there is no investor that generates over profits from the market condition, therefore; the investor does not make profits level by utilizing the existing public information. It also indicates that the investor is still aware of buying stock and the investor has a different preference to the 
implementation of the stock buyback announcement of PT Ramayana Lestari Sentosa Tbk and PT Ace Hardware Indonesia Tbk.

The result shows the existence of informationally efficient market in Indonesia Stock Exchange in the announcement of the stock buyback of PT Ramayana Lestari Sentosa Tbk and PT Ace Hardware Indonesia Tbk, which is informationally efficient market connects price and information connecting price and information state that a market is said semistrong form if the security prices fully reflect all publicly available information including information in the financial statements of the issuer company. In other words, the investor cannot make profits level above the normal by utilizing the existing public information.

It was also in relevant with decisionally efficient market theory stating that not all information received by market will directly be used to make a decision of a particular asset. On the other hands, the information will be interpreted in advance so that can be concluded that the most important factor in new information relevantly can be accepted by the market is sophistication of market player in interpreting that new information as a good or bad news. The result also can be interpreted that the investor considers that the stock buyback of PT Ramayana Lestari Sentosa Tbk and PT Ace Hardware Indonesia Tbk never contained strong enough information to influence investor in his/her decision making a decision because the investor tends to see that the announcement of that stock buyback is something having no big economical influence on the expected result. If connected to the business sector of PT Ramayana Lestari Sentosa Tbk and PT Ace Hardware Indonesia Tbk engaging in the retail service, the investor considers that stock buyback of PT Ramayana Lestari Sentosa Tbk and PT Ace Hardware Indonesia Tbk cannot give a real abnormal return yet in the future.

If reviewed from the abnormal return variable, this research result is in accordance with the previous result in Indonesia capital market, such as conducted by Dephinea (2016) giving an insignificant result of abnormal return.

The Result of Hypothesis III. The result of the statistical test on Hypothesis III generates that there is a difference of cumulative abnormal return of PT Ramayana Lestari Sentosa Tbk and PT Ace Hardware Indonesia Tbk before and after the announcement of the stock buyback. The result of the hypothesis test of the stock cumulative abnormal return before and after the announcement of the stock buyback at PT Ramayana Lestari Sentosa Tbk and PT Ace Hardware Indonesia Tbk results in that the stock buyback announcement has a big enough content of information to influence the investor in making a decision. That matter shows an undervaluation from the company's stocks conducting stock buyback in accordance with the theory explaining the reason of a company doing stock buyback, as said by Asquith and Mullin (1986) proposing that the stock buyback is a signal given by a company that its stock has a bigger intrinsic value than the market value (undervalued).

This result also shows the relevance to the signaling theory stating that a company, when having a stock buyback, gives a signal to the market that its stock is undervalued and the market gives a positive reaction to this signal. The more undervalued a stock, the bigger the positive reaction of the market signed by the higher the value of cumulative abnormal return obtained. In accordance with the signaling hypothesis stating that the stock buyback is a manager's notification of information about company's prospect in the future in the form of value increasing information reflected by the stock price increase of a company directly will impact on the company's value increase. That matter is in line with what proposed by Wansley, Lane, and Sarkar (1989) relating to the company's reason why conducting stock buyback. They said that the reason of a company to make a stock buyback is due to assessing that the stock is undervalued so that will be there wealth transfer from participating stockholder to the nonparticipating stockholder.

This research result supports and is in accordance with the previous research at a capital market in the foreign country, like a study conducted by Mohanty and Panda (2011), Rajagopalan and Shanker (2012) conducting a research in India capital market that all of them generate a significant result of cumulative abnormal return. 


\section{CONCLUSION}

Based on the testing result to the hypothesis and discussion so it can be drawn several conclusions as follows:

The result of calculation and return analysis on 10 days before and 10 days after the announcement of the stock buyback of PT Ramayana Lestari Sentosa Tbk and PT Ace Hardware Tbk that the return increases. The testing result of hypothesis 1 by using paired sample t-test shows that based on the statistical test, there is no significant difference of return before and after the announcement of the stock buyback, this means $\mathrm{H}_{0}$ is accepted and $\mathrm{H}_{1}$ is rejected. It shows that the announcement of the stock buyback does not give a positive signal to the investor so that not increasing total company's stock demands.

The calculation result and analysis of abnormal return on 10 days before and 10 days after the announcement of the stock buyback of PT Ramayana Lestari Sentosa Tbk and PT Ace Hardware Indonesia Tbk shows that abnormal return increases. The testing result of hypothesis II by using paired sample t-test shows that based on statistical test, there is no significant difference of abnormal return before and after the announcement of the stock buyback, this means $\mathrm{H}_{0}$ is accepted and $\mathrm{H}_{2}$ is rejected. This research result shows that the announcement of the stock buyback does not give a positive signal to that investor that does not quickly give a signal to buy company's stock buyback.

The result of calculation and analysis of cumulative abnormal return on 10 days before and after the announcement of the stock buyback of PT Ramayana Lestari Indonesia Tbk and PT Ace Hardware Indonesia Tbk shows that cumulative abnormal return increases. The testing result of hypothesis III by using paired sample t-test shows that based on the statistical test, there is a significant difference of cumulative abnormal return before and after the announcement of the stock buyback which means $\mathrm{H}_{3}$ is accepted and $\mathrm{H}_{0}$ is rejected. This research result shows that the announcement of the stock buyback gives a positive signal to the investor. It shows the relevance to the signaling theory, which is when a company carrying out stock buyback gives a signal to the market that company's stock is undervalued and market gives positive reaction to the signal. That matter is in accordance with the theory of a company's reason to buy stock buyback, that the stock buyback is a signal given to the company that its stock has a bigger intrinsic value than its market price (undervalued).

\section{SUGGESTIONS}

Based on the research result and conclusion that has been proposed previously, some suggestions offered are as follows:

- For Company. In order to apply the stock buyback policy, a company should consider its business sector and the preference of investor in investing.

- For Investor. In terms of making a long-term investment, the investor should consider the company's stock making buyback which can give a bigger cumulative abnormal return than before the company does the stock buyback.

A future investor is expected to be more selective and accurate in assessing whether an event of stock buyback conducted by a company has an information content or not, as well as whether or not that information is able to give economic value for investment made by investor so that in making a decision related to the event can be more accurate and correct. An investor should consider a policy made by a company such as the announcement of the stock buyback because it contains information that can be served as a consideration in carrying out investment decision-making correctly.

- For Future Researcher. The observation period is relatively short so that the return, abnormal return, and cumulative abnormal return reflect short-term value. It needs an advanced research if in the future total company making stock buyback is getting higher. A future study of the stock buyback research fatherly can be developed by seeing the relationship between cumulative abnormal return obtained by investor by the reason of a company making a stock buyback policy and growth level. 


\section{REFERENCES}

1. Asquith, P., and Mullins, D. W. (1986). Signalling with Dividends, Stock Repurchases, and Equity Issues Source. Financial Management, 15(3), 27- 44.

2. Darmadji, T., and Fakhruddin, H. M. (2001). Pasar modal di Indonesia. Jakarta: Salemba Empat.

3. Delphinea, N. (2016). Pengaruh Pengumuman Pembelian Kembali Saham (Buy Back) Terhadap Reaksi Pasar (Studi pada Perusahaan Terdaftar di Bursa Efek Indonesia (BEI) Tahun 2013-2015). Jurnal Administrasi Bisnis (JAB), 38(1), 25-34.

4. Fama, E. F. (1970). Efficient Capital Market: A Review of Theory and Empirical Work. Journal of Financial, 25, 383417.

5. Hartono, J. (2014). Teori Porto Folio dan Analisis Investasi. Yogyakarta: BPFE.

6. Husnan, S. (2005). Dasar-dasar Teori Porto Folio dan Analisis Sekuritas. Yogyakarta: UPP AMP YKPN.

7. Horne, V. J., and Wachowicz, J. (2005). Fundamentals of Financial Management. Jakarta: Salemba Empat.

8. Mohanty, M., and Panda, S. (2011). A Study on Investors' Reaction towards Share Buyback in India. European Journal of Social Sciences, 22(2), 34-42.

9. Rajagopalan, N. V. R., and Shankar. (2010). Buyback Announcements And Undervaluation Signalling In Indian Stock Market: A Study Of S\&P CNX 500 Index Companies. IJEMR, 2(1), 56-62.

10. Santoso, S. (2014). Statistik NonParametrik. Jakarta: PT Elex Media Komputindo.

11. Stephens, C., and Weisbach, M. (1998). Actual Share Reacquisitions In Open Market Repurchase Programs. Journal of Finance, 53, 313 - 334.

12. Sunariyah. (2006). Pengantar Penghetahuan Pasar Modal. Yogyakarta: UPP STIKOM YKPN

13. Wansley, J. W., Lane, W. R., and Sarkar. (1989). Management's View of Share Repurchases and Tender Premiums. Financial Management, 18, 97 - 110. 